\title{
Climate Change Vulnerability Analysis of Baluran National Park
}

\author{
Beny Harjadi \\ Balai Penelitian Teknologi Kehutanan Pengelolaan Daerah Aliran Sungai, \\ Jl. Ahmad Yani Pabelan Po. Box. 295, Solo, Telp. 0271-716759 \\ Corresponding author (e-mail: adbsolo@yahoo.com)
}

\begin{abstract}
Every ecosystem has a different level of susceptibility to environmental disturbances it receives, both from natural factors or anthropogenic disturbance. National Park (NP) Baluran is one national park that has a representation of a complete ecosystem that includes upland forest ecosystems, lowland forests, coastal forests, mangroves, savanna and evergreen forest. The objective of this study is to get a formula calculation of vulnerability analysis of constant and dynamic factors. Baluran NP vulnerability assessment to climate change done by looking at the dynamic and fixed factors. Vulnerability remains a vulnerability factor to the condition of the original (control), whereas vulnerability is the vulnerability of the dynamic change factors which affected the condition from the outside. Constant Vulnerability (CV) in Baluran NP dominated resistant conditions $(61 \%)$, meaning that the geomorphology and other fixed factors (slope and slope direction/aspect, then the condition in Baluran NP sufficiently resilient to climate change. Dynamic Vulnerability $(D V)$ is the vulnerability of an area or areas that change because of pressure from external factors. DV is influenced by climatic factors (WI = Wetness Index), soil $(S B I=$ Soil Brightness Index), and vegetation $(G I=$ Greenness Index $) . D V$ in Baluran NP from 1999 to 2010 shifted from the original category of being $(84.76 \%)$ and shifted to the susceptible $(59.88 \%)$. The role of remote sensing for the analysis of raster digital system, while the geographic information system to display the results of cartographic maps.
\end{abstract}

Keywords: Landsat Image, Radar, National Parks, Remote Sensing, GIS.

Abstrak. Setiap ekosistem mempunyai tingkat kerentanan yang berbeda terhadap gangguan lingkungan yang diterimanya, baik dari faktor alam maupun gangguan yang bersifat anthropogenic. Taman Nasional (TN) Baluran merupakan salah satu taman nasional yang memiliki keterwakilan ekosistem yang lengkap yang meliputi ekosistem hutan dataran tinggi, hutan dataran rendah, hutan pantai, mangrove, savanna, dan evergreen forest. Tujuan penelitian ini adalah untuk mendapatkan formula perhitungan analisis kerentanan dari faktor tetap maupun faktor dinamis. Penilaian kerentanan TN Baluran terhadap perubahan iklim dilakukan dengan melihat faktor dinamis dan tetap. Kerentanan tetap merupakan kerentanan dari faktor dengan kondisi asli (kontrol), sedangkan kerentanan dinamis merupakan kerentanan dari faktor berubah yang terpengaruh kondisi dari luar. Kerentanan Tetap (KRT) di TN Baluran di dominasi kondisi tahan (61\%), artinya secara geomorfologi dan faktor tetap lainnya (lereng dan arah lereng) maka kondisi di TN Baluran cukup tahan terhadap terjadinya perubahan iklim. KRD (Kerentanan Dinamis) merupakan kerentanan suatu wilayah atau kawasan yang berubah karena adanya tekanan dari faktor luar. KRD dipengaruhi oleh faktor iklim (WI=Wetness Index), tanah (SBI=Soil Brightness Index), dan vegetasi (GI=Greenness Index). Kerentanan Dinamis (KRD) di TN Baluran dari tahun 1999 ke tahun 2010 bergeser dari yang semula kategori sedang $(84,76 \%)$ dan bergeser ke rentan $(59,88 \%)$. Peran penginderaan jauh untuk analisis dengan sistem raster secara digital, sedangkan sistem informasi geografis untuk menampilkan hasil peta secara kartografi.

Kata kunci: Citra Landsat, Radar, Taman Nasional, Penginderaan Jauh, SIG.

\section{Introduction}

Mettzger et al. (2006) and IPCC (2007) define vulnerability as a function of exposure, sensitivity of a system to change and the adaptive capacity it possesses. Vulnerability can also be defined as the degree of ease of an affected system or the inability to tackle impacts, including the impacts derived from 
climate variability and extreme condition. Every landscape has different level of vulnerability to environmental disturbances, either natural or anthropogenic. Damages to landscape tend to vary due to different level of vulnerability.

National park is one of interesting landscapes to study. According to Act Number 5 Year 1990 on Biological Resources Conservation and their Ecosystem, a national park shall be a nature conservation area which possesses native ecosystem, which is managed through a zoning system utilized which facilitates research, science, education, breeding enhancement, recreation and tourism. Baluran National Park is one of national parks with complete representations of ecosystem. It is the representation of highland, lowland, and beach forest, mangrove, savanna, and evergreen forest (Government Regulation of Ministry of Forestry, 2009).

Baluran National Park and its ecosystem components may show different vulnerability level to the factors influencing ecosystem, either in terms of biotic, abiotic, or anthropogenic factors, depending on the area and forest type, geographical condition, and cultural background of the communities surrounding the forest. Pressure from those factors will affect human and forest ecosystem. The influence magnitude depends on the forest ecosystem's sensitivity and adaptive capacity, as well as management capability. Negative effect will increase in the future, unless earlier handling is done.

Harjadi (2005) assumes that details on vulnerability require high accuracy on land acreage which can be analyzed using geographic information system (GIS). Assessment for biophysical condition is carried out by considering static physical factors (inclination and slope direction, and elevation) and the dynamic physical factors (soil brightness and wetness, and canopy closure). According to CSSTEAP (2005), dynamic factors can be measured by satellite analysis, including Soil Brightness Index (SBI), Wetness Index (WI) and Greenness Index (GI).

This research aims to create a formula to analyze vulnerability assessment, both from static and dynamic factors. Vulnerability analysis can assist in the preparation of policies relating to the area management plans in the future

\section{Research Method}

\section{a. Research Location}

The research was conducted at Baliuran National Park, East Java in 2010. Baluran National Park $(25,000$ ha) is located in Banyuputih, Situbondo Regency, East Java (based on the Decree of Ministry of Forestry, 1997). It is geographically situated on the coordinates of $7^{\circ} 45^{\prime}-7^{\circ} 15^{\prime}$ South and $114^{\circ} 18^{\prime}$ $114^{\circ} 27$ East, the southeast of Java island (Figure 1). It is bordered by Madura Strait in the north, Bajulmati River in the west, Bali Strait in the east, and Klokoran River in the northwest.



Figure 1. Research Sites in Baluran National Park (yellow circle)

Baluran National Park was granted as a National Park due to the Decree Letter of Ministry of Forestry dated May $23^{\text {rd }} 1997$, covering an area of 25,000 ha. In accordance with the allocation, the territory of the area is divided into some zones as mentioned in the Decision Letter of Directorate General of Nature Protection and Conservation Number 187/Kpts./DJ-V/1999 dated December $13^{\text {th }}$ 1999, which consists of: core zone covering 12,000 ha, wilderness zone covering 5,537 ha (Waters=1,063 ha and Land $=4,574$ ha), intensive utilization zone covering 800 ha, specific utilization zone covering 5,780 ha, and rehabilitation zone covering 783 ha.

\section{b. Materials and Equipments}

Materials needed in this research include:

1) Basic maps, including RBI map (Indonesia Topographical Map) at the scale of 1:25,000 (contour and land cover map), land system 
map, and situation and administration map.

2) Recording of Landsat Enhan-ced Thematic Mapper 7 (TM7) image in August 1999 and 2010.

3) SRTM (Shuttle Radar Topo-graphic Mission)

4) Stationeries and writing tools for image interpretation, including fine full color OHP markers, scotch-tape and astralon plastic.

5) Plotting paper, printing paper, and cartridge ink (black, yellow, magenta and cyan). follow:

Meanwhile, the equipments needed are as

1) Equipments for interpreting satellite image visually (loop, mirror/pocket stereoscope, and computer)

2) Equipments for field survey (compass, abney level, $\mathrm{pH}$ stick, field forms, digital camera and Global Positioning System (GPS)

3) Equipments for analyzing digital data and SIG, including:

a) Hardware (computer)

b) Software for image analysis that consists of Erdas-Imagine 8.7 version and PC Arc/Info 3.4D plus version, and Ilwis 3.3. Excel, Microsoft Word, and DBASE III Plus for tabulation purpose.

\section{c. Data Collection Technique}

\section{1) Climate data}

Climate data are obtained from the nearest BMKG (Badan Meteorologi Klimatologi dan Geofisika) or the Meteorogical, Climatological and Geophysical Agency of Baluran National Park, located in Banyuwangi. The data include annual temperature, maximum average temperature, minimum average temperature, average maximum air pressure, average maximum humidity, average minimum humidity, and sum of rainy days in a year, from 1981 to 2007. Variables in the scope of weather consist of temperature, precipitation capacity, air pressure, air humidity, speed, and wind direction. Meanwhile, climate is the average condition of atmosphere, and it deals with topographical characteristics and water surface width in a certain region, within a certain respective period in years (McMichael, 2003). Conceptually, changes of one or more climate dimensions (e.g. temperature and rainfall) will influence the process of ecosystem (forest) (Ayres, et.al. 2009). The process of forest ecosystems will impact on population changes in flora and fauna.

\section{2) Land biophysical data}

Land biophysical data collecting, according to Harjadi (2007), is carried out with land resources inventory, consisting fixed factors (landform, types of rocks, types of soil, and slope inclination) together with dynamic factors (erosion, terrace, land cover, and land use capability). Furthermore, there are some factors used in analyzing satellite image to calculate Constant Vulnerability (CV) and Dynamic Vulnerability (DV). To measure constant vulnerability, data of slope inclination (slope), slope direction (aspect), and altitude are required. Data slope, aspect and elevation follows the formula already provided by the ILWIS soft ware. Meanwhile, to calculate dynamic vulnerability, data of land wetness (WI), soil brightness (SBI), and level of plant greenness (GI) are needed. Furthermore, the classification to determine areas that have high levels of vulnerability to climate : highly resistant, resistant, medium, vulnerable and Particularly vulnerable.

\section{3) Ecosystem-change data}

Ecosystem-change data are needed to analyze the changes of land cover (flora) and changes of fauna as the result of climate change. For example, there were a large number of oxen and bulls, but now, the numbers are decreasing because of the decreased water reservoirs and width of savanna. Ecosystems for observation purposes include the lines between coastal and mangrove ecosystems, between mangrove and lowland ecosystems, between savanna and evergreen ecosystems, between evergreen and lowland ecosystems, and between lowland and highland ecosystems. So that the adaptive capacity of an ecosystem will change according to the climatic conditions. In this case adaptive capacity is defined as "the ability of a system to cope with the consequence of climate change/ climate variations or to adapt with climate change/climate variations (including climate variability and extreme climate), reduce 
potential for any damage, or take advantage of condition resulted from dynamic climate" (McCarthy et al., 2001 in Locatelli et al., 2008).

\section{Data Analysis}

Scoring method is employed to assess vulnerability value. Method of calculating the value of vulnerability conducted by scoring, by summing the three variables, if the value $<50$ (very vulnerable), 50-100 (vulnerable), 100150 (moderate), 150-200 (resistant),> 200 (very resistant). Vulnerability in the research location shows spatial and degree variations, and then Vulnerability Status Index (VSI) is obtained. Vulnerability analysis is carried out in two ways, consisting of CV with SRTM image, and DV with Landsat image taken in 1999 and 2010. On the basis of the vulnerability status, it is found that the maximum vulnerability value is 150 while the minimum value is 0 . The value is categorized into 5 classes including very high (very vulnerable), high (vulnerable), moderate, low (invulnerable), and very low (very invulnerable).

By using remote sensing analysis results, the formula for assessing vulnerability with CSSTEAP (2005) is translated into dynamic vulnerability (DV):

\section{$\mathrm{DV}=\mathrm{GI}+\mathrm{WI}+\mathrm{SBI}$}

Note:

GI : Greenness Index or greenness level of plants

WI : Wetness Index or level of humidity/ wetness/area- covering

SBI : Soil Brightness Index or level of soil brightness.

Thus, assessment of DV can be done by comparing two satellite images taken in different time. Besides, by using image SRTM, $\mathrm{CV}$ can be calculated with the following formula:

\section{Constant Vulnerability $=$ Slope + Aspect + Altitude}

Note:

Slop : level of slope

Aspect : level of slope direction

Altitude : level of height asl (above sea level)

\section{Result and Discussion}

The calculation of vulnerability in Baluran National Park is conducted by considering dynamic and fixed factors. Constant vulnerability is the level of vulnerability influenced by real condition factors (control), while dynamic vulnerability is the vulnerability caused by external factors. Constant factor consists of slope, inclination, and altitude, while dynamic factor comprises GI and SBI.

Indications of climate change (season variations and extreme weather) in Baluran National Park is identified from the increasing tendency in some climate parameters. They are annual temperature $\left(26.40^{\circ} \mathrm{C}-27.50^{\circ} \mathrm{C}\right)$, average maximum temperature $\left(27.30{ }^{\circ} \mathrm{C}-28.70{ }^{\circ} \mathrm{C}\right)$, average minimum temperature $\left(24.20^{\circ} \mathrm{C}-26.80\right.$ ${ }^{\circ} \mathrm{C}$ ), average maximum air pressure (1010.2 mb-1015.4 mb), average minimum air pressure (1004.8 mb-1009.5 mb), average maximum air humidity (79\%-86\%), average minimum air humidity $(69 \%-78 \%)$ as well as the amount of rainfall per year (102-206 days). Annual rainfall and maximum rainfall are relatively constant.

$\mathrm{CV}$ does not relatively change in some years, however, in more than 100 years of geological age, it possibly shows slow changing. In tropical area, geological change is caused by disintegration of bedrock split and decomposition is due to chemical process, and therefore, these lead to the changes of geomorphology and soil nature. These changes provide the foundation for DV measurement. Thus, some years of change even will cause vulnerability of plants, soil, and ecosystem to change.

\section{a. Constant Vulnerability (CV)}

$\mathrm{CV}$ shows the level of land change due to internal factor which is relatively unaltered. Some factors that influence constant vulnerability are: altitude, slope and aspect. To obtain the data from the field, sometimes have difficulty, especially in most remote places or dangerous, so that satellite image remote sensing is necessary. Radar image SRTM can provide the information to measure altitude, slope, and aspect. Then, the grouping process is carried out shown in Figure 2. 


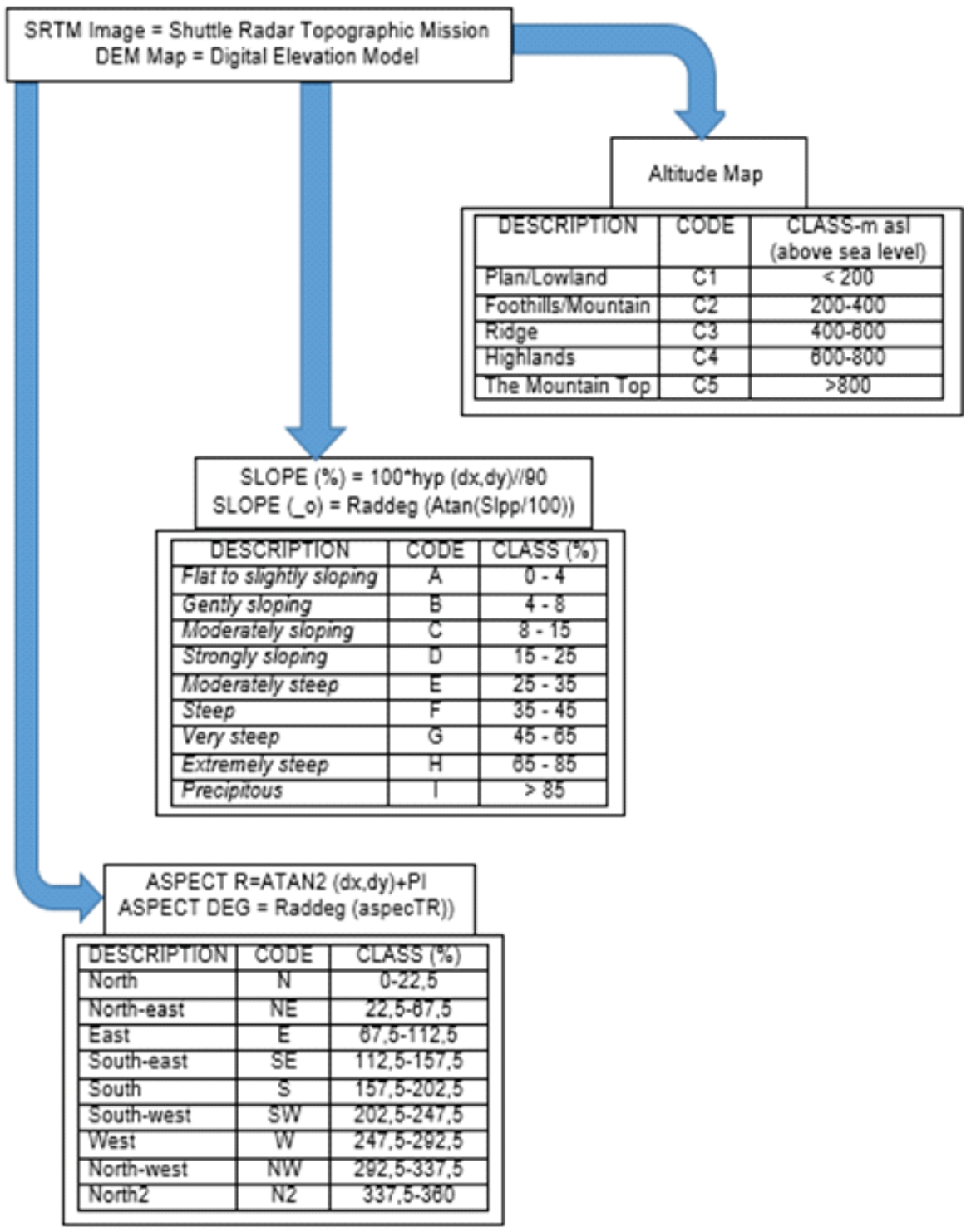

Figure 2. Flow Chart of Component Calculation CV (Constant Vulnerability): Altitude Place, Slope and Slope Direction (Aspect)

\section{b. Slope}

Slope in Baluran National Park is classified into 8 classes. They are: A (Flat $<4 \%$ ), B (Rather Slope 4-8\%), C (Slope 8-15\%), D (Very Slope 15- 25\%), E (Rather Steep 25-35\%), F (Steep 35-45\%),G (Very Steep 45-65\%), H (Extremely Steep 65-85\%), I (Abrupt >85\%). The most part of land is flat slope (A) which causes the land relatively easy to be cultivated and used as grazing land primary in the savanna area (Figure 3). Land with rather steep slope (E) to Abrupt (I) is not too large; however, it is potential as source of erosion disaster when the rain comes down with high intensity (Harjadi, 2004).

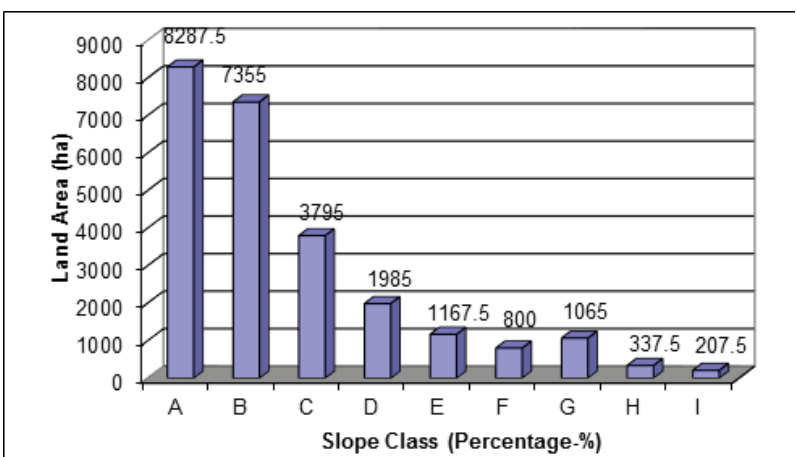

Figure 3. Distribution of Slope in TN Baluran, Dominated by Region Plains $(A=0-4 \%)$ and Few is Steep (I> 85\%) 


\section{c. Aspect (Slope Direction)}

The distributions of aspect are equitable into every part of direction from $\mathrm{N}$ (North), NE (North East), E (East), SE (South East), S (South), SW (South West), W (West), NW (North West), and N2 (the second North) as presented in Figure 4. The land of Baluran
National Park which is dominated by North direction (16) experienced to light erosion, then in the SE (South East: 14\%) and South (13\%) experienced heavy erosion, and land in the East (12\%) and North East (13\%), the sensitivity towards erosion is low (NW, E, NE), medium (W\&E), and heavy (SW, S, SE).

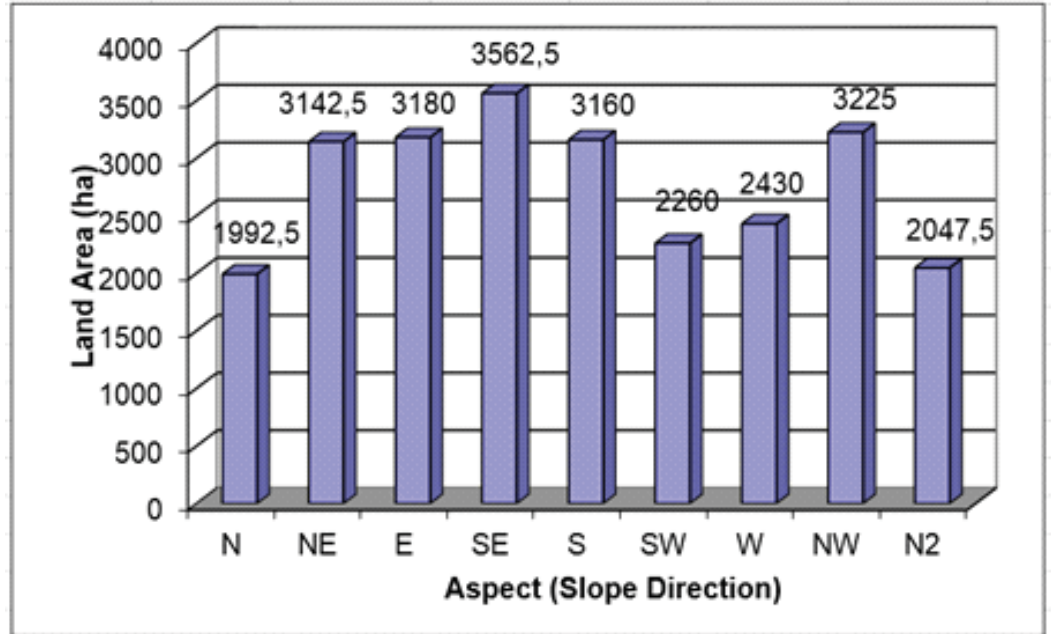

Figure 4. Directions of Slope at TN Baluran to all Wind Directions, Most is to the North (N+N2) and Least is to the Southwest (SW).

\section{d. Altitude}

Most of the land $(65 \%)$ in Baluran National Park is lowland $(<200 \mathrm{~m}$ above sea level) and slopes of mountain $(22 \%)$, and therefore, the areas are relatively resistant to any external disturbance. Even though the top of the mountain is not wide enough, it easily experiences erosion and is easily transported or shifted if eruption takes place (Figure 5).

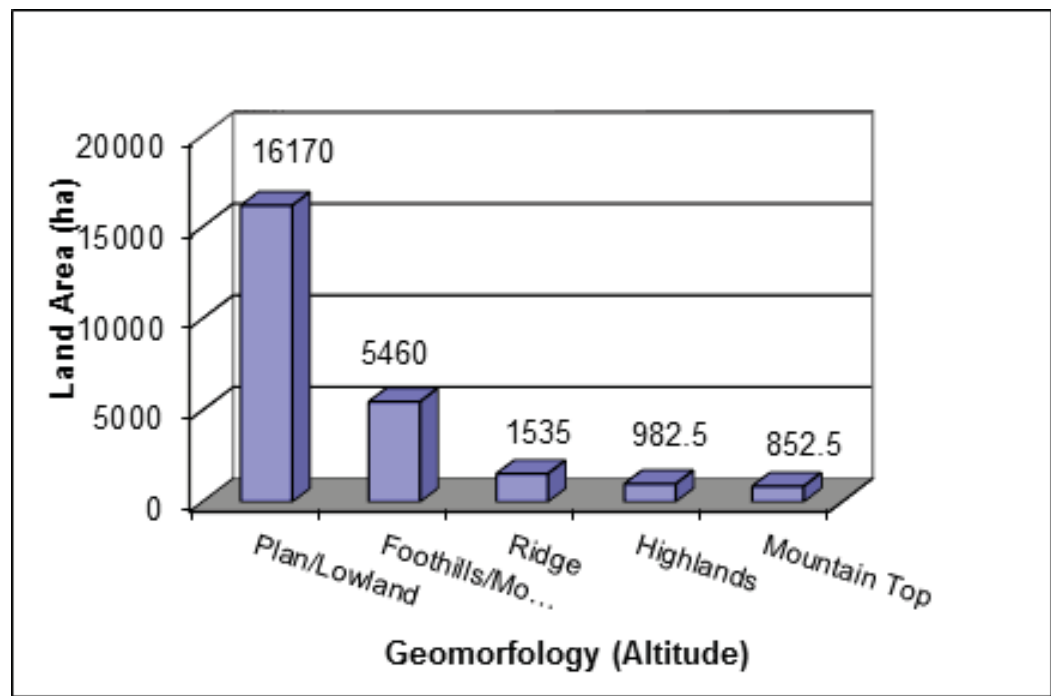

Figure 5. Geomorphology Conditions in TN Baluran, the most is Lowland (16 170 ha) and the least that is Peak of Mount (852 ha).

$\mathrm{CV}$ in Baluran National Park is dominated by resistant condition (61\%), which means that in terms of its geomorphology and other constant factors (the slope and slope direction), the condition in Baluran National Park is quite resistant to the climate changes (Figure 6). 




Figure 6. Distribution Map of CV in TN Baluran which is Dominated by Resistant Condition (61\%) of the changes based on SRTM Image Analysis

\section{e. Dynamic Vulnerability (DV)}

Dynamic vulnerability is the vulnerability of an area or region which changes due to some pressures of external factors. DV is affected by climatic factor (WI/Wetness Index), soil (SBI), and vegetation (GI/Greenness Index) seen on Figure 7. If data taken from the field are required, either they are difficult to provide or some are found occasionally missing from the record in the previous years, assistance from the data taken from satellite image recorded once a month is very significant. To compare and contrast whether there are changes of dynamic vulnerability, it is necessary to provide those data taken in the same month of different year.

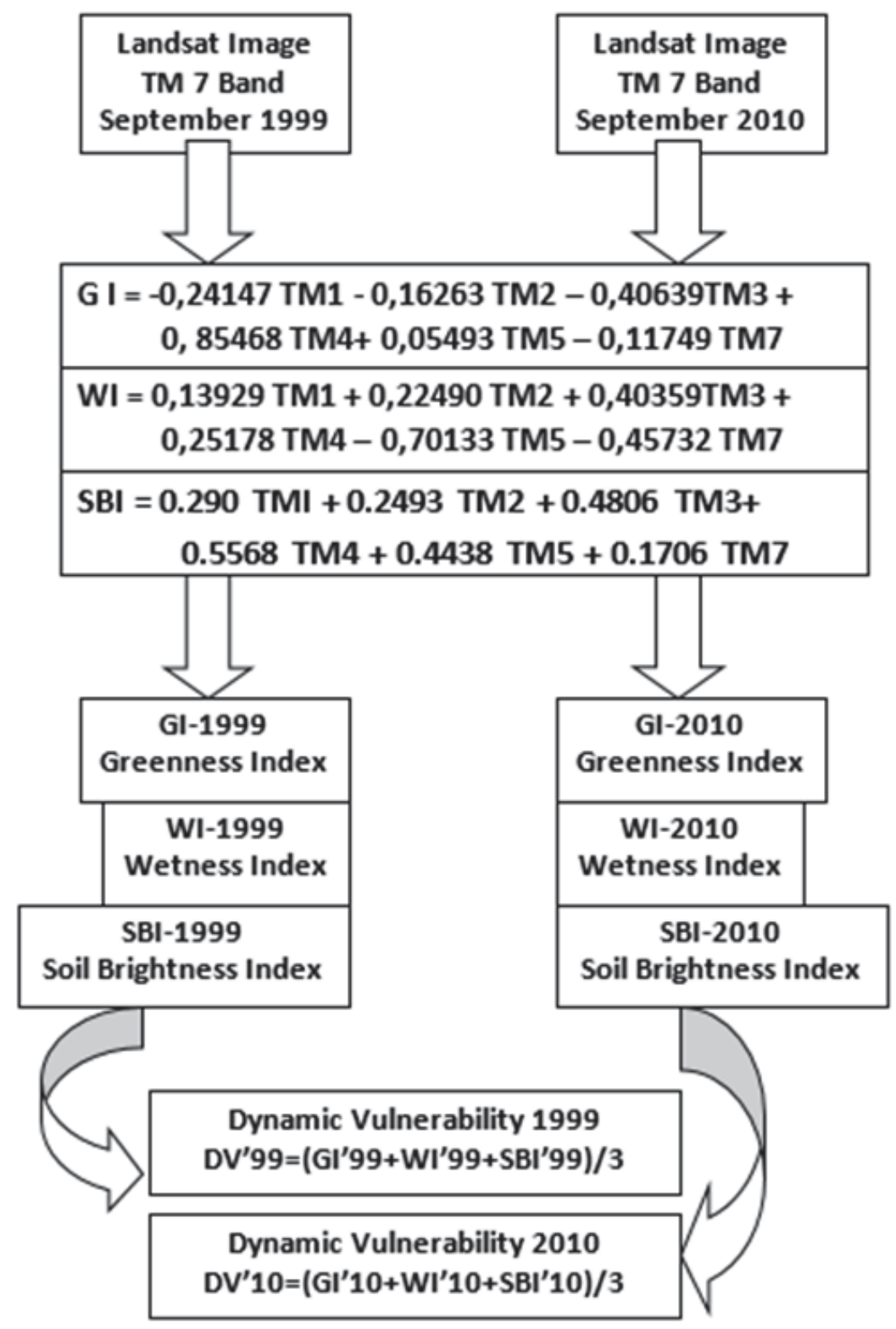

Figure 7. Chart of DV Calculation due to changes of GI, WI, and SBI 


\section{f. GI (Greenness Index)}

Transformation greenness index indicates that the closer the vegetation will provide a high index value. Transformation of Greenness Index presents that the denser the vegetation is, the higher the index value will be. The transformation of GI makes use of several channels, among others: TM 1, TM 2, TM 3, TM 4, TM 5, and TM 7. On the other hand, to the level of greenness plummeted (32\% to $21 \%$ ) as seen on Figure 8.



Figure 8. Greenness Rate Changes (Greenness Index = GI) in TN Baluran from 1999 to 2010

\section{g. WI (Wetness Index)}

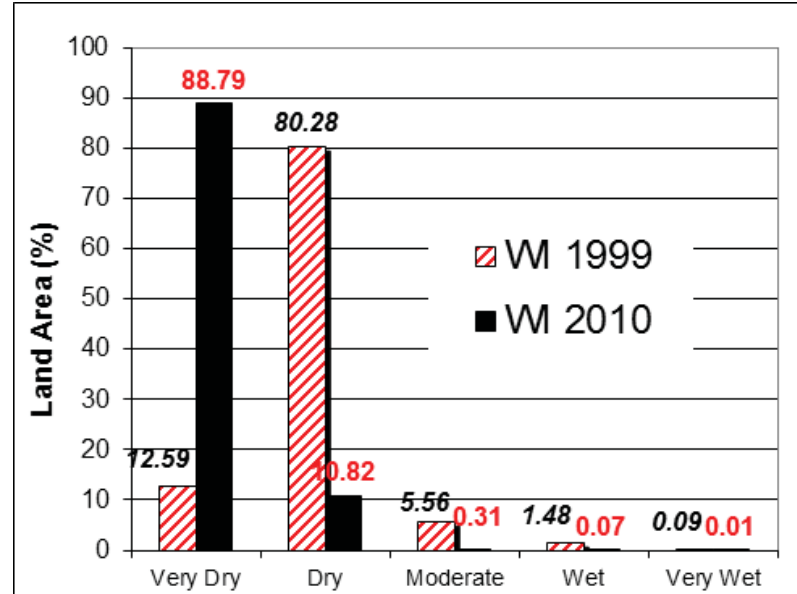

Class of Wetness Index (WI) 1999 dan 2010

Figure 9. Changes of Humidity Level (Wetness Index = WI) in TN Baluran from 1999 to 2010

Topographic wetness index (TWI), also known as the compound topographic index (CTI), is a steady state wetness index. It is commonly used to quantify topographic control on hydrological processes. Fluid contained in leaves will provide index to vegetation. Transformation of WI employs several spectral channels, among others: TM1, TM 2, TM 3, TM 4, TM5, and TM 7. In Landsat image taken in 1999, most of the areas were in the dry condition $(80 \%)$ and very dry $(12 \%)$, whereas in 2010 , most were very dry $(88 \%)$ and dry $(11 \%)$ (attached in Figure 9). The 2010 Landsat image was either dominated by moderate $(63 \%)$ and dense $(21 \%)$ land closure, and also sparse land closure $(15 \%)$.

\section{h. SBI (Soil Brightness Index)}

SBI is the soil brightness as a result of sun light, meaning that the wider an open land is, the higher the land brightness can be, and on the other way, when a land is dense, less light reflection and absorption will occur. Dense land closure dominates Baluran National Park, hence, the SBI becomes dark (a little reflection), i.e. $87 \%$ in 1999, and $78 \%$ in 2010 (Figure 10).

The dynamic vulnerability in Baluran National Park from 1999 to 2010 shifted from moderate $(84.76 \%)$ to vulnerable $(59.88 \%)$. The condition is triggered by a globally extreme climatic change (Figure 10). With the condition of cosntant vulnerability that is resistant or not very vulnerable, climatic change do not give too much negative impact to the ecosystem of the flora and fauna in Baluran National Park.

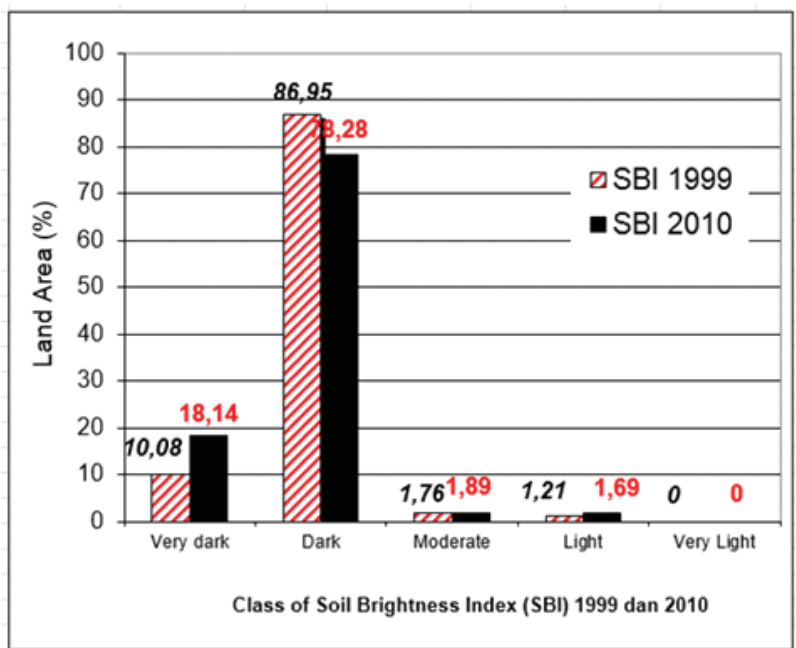

Figure 10. Changes of Brightness Level (SBI) in TN Baluran from 1999 to 2010

DV in TN Baluran from 1999 to 2010 shifted from the medium category $(84.76 \%)$ to the vulnerable category (59.88\%). It was due to the 
extreme change of global climate (Figure 11). With the condition of vulnerability remained resilient and dynamic vulnerability which was not until very vulnerable, the climate change was not too bad for the ecosystem, flora and fauna in TN Baluran.

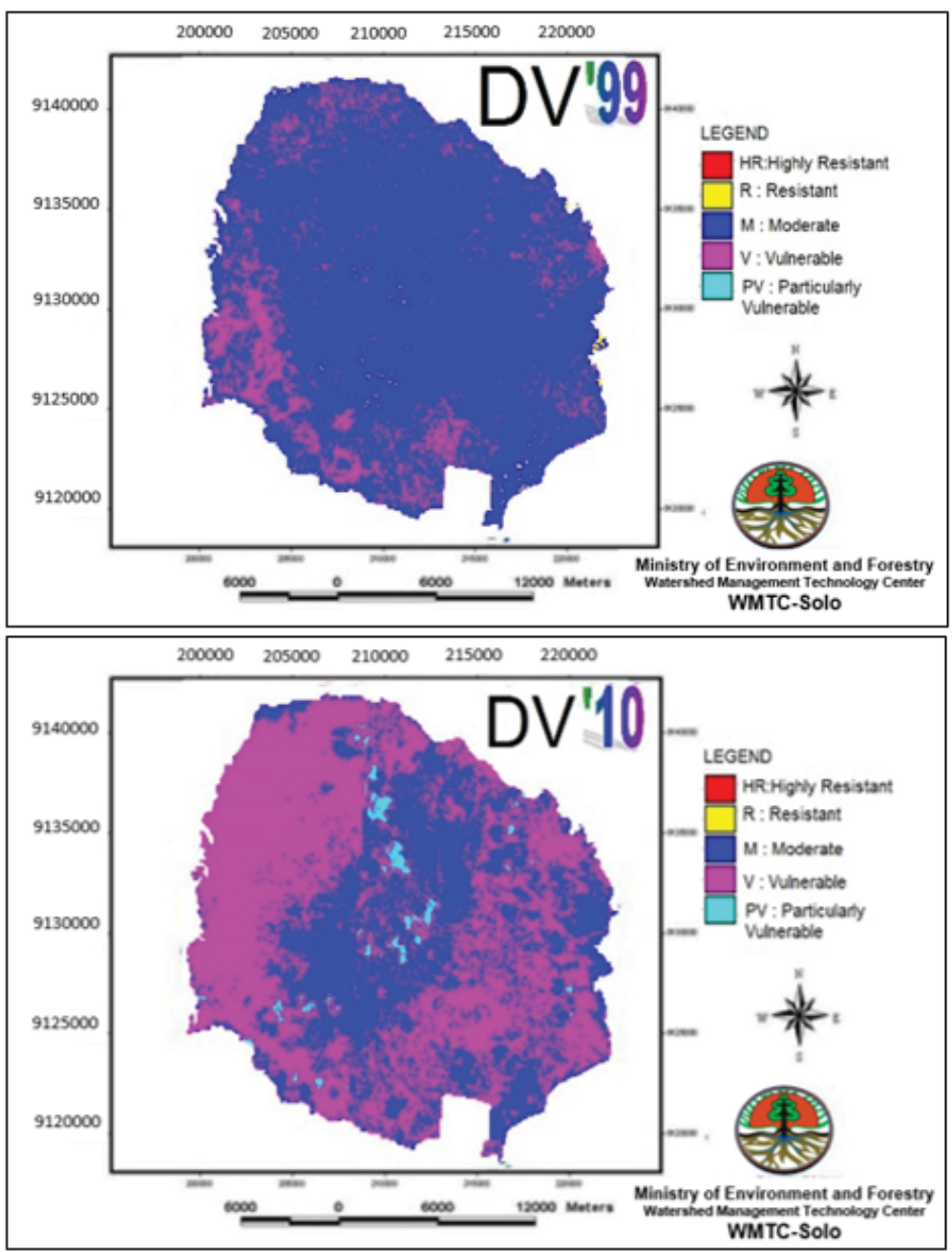

Figure 11. Changes of DV in a decade (1999-2010) in TN. Baluran, Situbondo.

\section{Conclusion}

$\mathrm{CV}$ (Constant Vulnerability) is influenced by fixed factors which are very influential on the vulnerability level of an area, such as in the TN Baluran which is influenced by altitude, slope and slope direction. At TN Baluran (The National Park of Baluran), CV is dominated by impervious areas ( $61 \%$ ), so that the pressure from outside factors do not cause the area to become vulnerable .

DV (Dynamic Vulnerability) is affected by the climate (WI), soil (SBI) and vegetation (GI) which are the external factors that often change dynamically at any time. CV in TN Baluran shifted from the medium category $(85 \%)$ into a vulnerable category $(60 \%)$, so it is needed to be aware if there is a change due to land clearing, climate change and soil fertility.
Both of these vulnerabilities CV and DV strengthen each other, if both include climate resistant to external factors as it will be resistant to change. Conversely, if both are vulnerable to external factors, it will be seriously affected if there is slightest pressure from the outside.

Formula for calculating the vulnerability of an ecosystem can be done by calculating the CV and DV. CV is influenced by altitude, slope and direction of the slope, while the DV is determined by climatic factors, soil and vegetation.

Remote Sensing satellite imagery and Geographic Information System have an important role in calculating the mountainous areas particularly for the places which are difficult to reach, or the dangerous areas due to a volcanic eruption or a large area. 
At Baluran TN region, the peak areas of the slope $>85 \%$ and the whole area is very large caldera is very difficult to reach because of the that is a total of 25,000 ha.

\section{References}

Ayres, Matthew, David Karnosky and Ian Thompson. 2009. Forest Responses and Vulnerabilities to Recent Climate Change dalam Adaptation of Forests and People to Climate Change (Risto Seppala, Alexander Buck, Pia Katila, editor). IUFRO World Series Volume 22.

CSSTEAP, 2005. Remote Sensing \& Geographic Information System, Lecture Notes, Module Ii : RS \& GIS Applications In Agriculture \& Soils, Post Graduate Course On Centre for Space Science \& Technology Education, In Asia \& The Pacifice (CSSTEAP). Indian Institute of Remote Sensing (National Remote Sensing Agency), Dehradun, India, (Affiliated to The United Nations), IIRS Campus, Dehradun, India

Decree of Ministry of Forestry, 1997, SK Menhut : Penetapan Luasan Kawasan Taman Nasional Baluran 25.000 Hektar. SK. Menteri Kehutanan No. 279/Kpts.-VI/1997 tanggal 23 Mei 1997, Jakarta.

Harjadi B., 2004. Karakteristik Sumberdaya Lahan Sebagai Dasar Pengelolaan DAS di Sub DAS Merawu, DAS Serayu. Jurnal Geografi Universitas Muhammadiyah Surakarta, Forum Geografi, Vol.18, No.2, Desember 2004

Harjadi, B. 2007. Aplikasi Penginderaan jauh dan SIG Untuk Penetapan Tingkat Kemampuan Penggunaan Lahan (KPL), Studi Kasus di DAS Nawagaon Maskara, Saharanpur-India. Forum Geografi vol.21 No.1, Juli 2007. Suarakarta. P 60-77.

Harjadi, B., 2005. Deteksi Kekritisan Lahan dengan Penginderaan Jauh dan Sistem Informasi Geografi (Studi Kasus Lahan Kritis Sub DAS Alang, Wonogiri). Jurnal Geografi Universitas Muhammadiyah Surakarta, Forum Geografi, Vol.19, No.1, Juli 2005.

IPCC. 2007. Impact, adaptation and vulnerability. Contribution of Working Group II to the Fourth Assessement Report of the Environmental Panel on Climate Change (IPCC). Parry, M.L., Canziani, O.F., Palutifof, J.P., van der Linden, P.J. and Hanson, C.E. (eds.). Cambridge University Press, Cambridge, UK. 973 p.

Locatelli, Bruno, Markku Kannined, Maria Brockhaus, Carol J.P. Colfer, Daniel Murdiyarso, dan Heru santoso. 2008. Facing an uncertain future. How forests and people can adapt to climate change. Forest Perspectives 5. CIFOR. Indonesia

McMichael. 2003. Climate Change and Human Health: Risks and Responses. WHO. Jenewa.

Mettzger, M.J., Rounsevell, M.D.A., Acosta-Michlik, L., Leemans, R. and Schroter, D. 2006. The vulnerability of ecosystem services to land use change. Agriculture Ecosystem and Environment 114: 69 - 85. 